\title{
Identifying targets for diagnosis, prognosis, and treatment
}

\section{OPEN}

Josep Dalmau, MD, PhD This issue of Neurology ${ }^{\circledR}$ Neuroimmunology \& Neuroinflammation (N2) incorporates exciting studies on the biology of immunologic and inflammatory biomarkers and the importance of knowing the benefits and complications of targeted therapies. In addition, the issue includes several clinically relevant reports on viral and autoimmune encephalitis. The concept of precision medicine, recently re-enhanced by public media, is not new in clinical and basic research. An interesting example is the case presented by Euskirchen et al. ${ }^{1}$ of a patient with life-threatening brainstem neurohistiocytosis in the context of Erdheim-Chester disease and cutaneous Langerhans cell histiocytosis. Detection of a BRAF mutation in affected tissues led to the selection of a specific BRAF inhibitor (vemurafenib), resulting in a rapid clinical response. On the other hand, Kornberg et al. ${ }^{2}$ suggest that the use of targeted therapies in an inappropriate context, such as fingolimod and natalizumab in neuromyelitis optica (NMO) instead of multiple sclerosis (MS), carries the risk of disease exacerbation. The authors postulate that a combination of drug effects, including an increase of blood-brain barrier permeability allowing CNS entry of Th17 lymphocytes, was responsible for the clinical worsening in the case they present. In another report, Hillen et al. ${ }^{3}$ postulate that natalizumab may have contributed to fulminant liver failure related to hepatitis $\mathrm{B}$ infection in a patient receiving the drug for relapsing-remitting MS (RRMS). Svenningsson et al. ${ }^{4}$ show that rituximab, a drug used for both MS and NMO, rapidly distributes to the peripheral compartment following intrathecal administration. Ultralow doses of intrathecal rituximab were sufficient to cause complete and prolonged depletion of B lymphocytes in both the CNS and systemic compartments, an observation with potential implications for other disorders, such as autoimmune encephalitis.

Three additional studies use immunologic cells or autoantibodies as biomarkers of disease or treatment outcome. In a study of children with a first episode of acquired demyelinating syndrome, Hacohen et $\mathrm{al}^{5}$ found that the presence of myelin oligodendrocyte glycoprotein (MOG) antibodies at symptom onset predicted a non-MS disease course. These findings confirm previous studies indicating that patients with optic neuritis and MOG antibodies have a low probability of developing MS or NMO. ${ }^{6}$ De Raedt et al. ${ }^{7}$ describe that the detection of a high circulating natural killer (NK) cell count within the first hours after an acute ischemic stroke, followed by a drop in all lymphocyte subsets, identifies patients prone to develop infections, likely as a result of autonomic dysfunction with sympathetic overdrive. Elkins et al. ${ }^{8}$ investigated the relationship between $\mathrm{CD} 56^{\text {bright }}$ NK cells and disease activity in patients with RRMS treated with daclizumab high-yield process (DAC HYP). In this preliminary study, the authors found a statistically significant inverse relationship between CD56 $6^{\text {bright }}$ NK cell counts measured after DAC HYP and the number of new or enlarged T2-hyperintense lesions that developed between weeks 24 and 52 posttreatment. The findings, which need validation in prospective studies, suggest that $\mathrm{CD} 56^{\text {bright }} \mathrm{NK}$ cell counts should be considered as a potential surrogate to understanding individual variation in the treatment response to DAC HYP.

A study by Bar-Or et al. ${ }^{9}$ provides Class II evidence that in normal subjects treated with teriflunomide (a drug used in RRMS that blocks pyrimidine synthesis), antibody titer responses to rabies vaccination are lower than with placebo but sufficient for seroprotection. The findings support the view that teriflunomide decreases autoaggressive immune responses in MS but does not limit the ability to mount primary adaptive humoral immune responses or alter delayed T-cell hypersensitivity. The work of Guptill et al. ${ }^{10}$ shows that patients with musclespecific tyrosine kinase myasthenia gravis have higher plasma B cell-activating factor levels and lower percentages of B10 cells than healthy controls. The authors suggest that the reduction of regulatory B10 cells, which produce the anti-inflammatory cytokine interleukin (IL)-10, likely explains a previously reported increase of proinflammatory Th1 and Th17

From the Catalan Institution of Research and Advanced Studies (ICREA) and Biomedical Research Institute August Pi i Sunyer (IDIBAPS), Hospital Clinic, University of Barcelona, Barcelona, Spain.

Funding information and disclosures are provided at the end of the article. Go to Neurology.org/nn for full disclosure forms.

This is an open access article distributed under the terms of the Creative Commons Attribution-Noncommercial No Derivative 3.0 License, which permits downloading and sharing the work provided it is properly cited. The work cannot be changed in any way or used commercially. 
responses, breaking down immune tolerance and resulting in the generation of autoreactive B cells. ${ }^{11}$ In another study, Moore et al. ${ }^{12}$ used human fetal and adult microglia to confirm that expression of the P2Y12 receptor (an ADP-responsive G proteincoupled receptor also expressed by platelets) is enhanced under alternatively activated (M2, IL-4, and IL-13) conditions, mediating cell migration and participating in acute proinflammatory responses toward dangerassociated molecules that are released during CNS injury. The findings may provide a novel strategy for treating CNS inflammatory disorders.

In the fields of viral, paraneoplastic, or autoimmune encephalitis, 5 interesting articles are included in this issue. Marques et al. ${ }^{13}$ describe a challenging case of varicella-zoster encephalitis mimicking toxoplasmosis relapse; the clinical and MRI features suggesting hemorrhagic encephalitis with vasculopathy were important clues to the diagnosis, which was confirmed with CSF viral studies. Liba et al. ${ }^{14}$ describe a patient with Rasmussen encephalitis who dramatically responded to aggressive immunotherapy with steroids, cyclophosphamide, and mycophenolate mofetil; the short clinical follow-up suggests caution in the interpretation of this intriguing result. Probst et al. ${ }^{15}$ confirm that a novel cell-based assay expressing Delta/ Notch-like epidermal growth factor-related receptor confers high sensitivity and specificity for determination of $\operatorname{Tr}$ antibodies, which usually occur in association with cerebellar degeneration and Hodgkin lymphoma. Körtvelyessy et al. ${ }^{16}$ provide the neuropathologic findings in the hippocampus and amygdala of a patient with autoimmune encephalitis and CASPR2 antibodies. Among moderate amounts of $\mathrm{CD}^{+}$and $\mathrm{CD}^{+} \mathrm{T}$ lymphocytes (without neuronophagic nodules) and small numbers of B cells and plasma cells, the authors found deposits of complement in a few neurons, suggesting a complement-mediated mechanism. The case is interesting because CASPR2 antibodies are usually $\mathrm{IgG4}$, an isotype that does not fix complement. Finally, Simabukuro et al. ${ }^{17}$ report a case of recurrent thymoma and autoimmune encephalitis associated with cortical and subcortical fluidattenuated inversion recovery MRI abnormalities and antibodies to both $\mathrm{GABA}_{\mathrm{A}}$ receptor and LGI1. The tumor expressed both autoantigens, and the patient had a remarkable recovery after tumor removal and immunotherapy. This case highlights the complexity of autoimmune encephalitis associated with several concurrent autoantibodies.

I hope you enjoy reading these articles and encourage you to submit your work to N2.

\section{DISCLOSURE}

J. Dalmau is the editor of Neurology: Neuroimmunology \& Neuroinflammation; is on the editorial board for Neurology UpToDate; holds patents for and receives royalties from Ma2 autoantibody test and NMDA receptor autoantibody test; has patent applications for and receives royalties from $\mathrm{GABA}(\mathrm{B})$ receptor autoantibody test, $\mathrm{GABA}(\mathrm{A})$ receptor autoantibody test, DPPX autoantibody test, and IgLON5 autoantibody test; and received research support from Euroimmun, NIH, and Fondo de Investigaciones Sanitarias de la Seguridad Social (Instituto Carlos III, Spanish Government). Go to Neurology.org/nn for full disclosure forms.

\section{REFERENCES}

1. Euskirchen P, Haroche J, Emile JF, Buchert R, Vandersee S, Meisel A. Complete remission of critical neurohistiocytosis by vemurafenib. Neurol Neuroimmunol Neuroinflamm 2015;2:e78. doi: 10.1212/NXI. 0000000000000078 .

2. Kornberg MD, Newsome SD. Unmasking and provoking severe disease activity in a patient with NMO spectrum disorder. Neurol Neuroimmunol Neuroinflamm 2015;2: e66. doi: 10.1212/NXI.0000000000000066.

3. Hillen ME, Cook SD, Samanta A, Grant E, Quinless JR, Rajasingham JK. Fatal acute liver failure with hepatitis B virus infection during natalizumab treatment in multiple sclerosis. Neurol Neuroimmunol Neuroinflamm 2015;2: e72. doi: 10.1212/NXI.0000000000000072.

4. Svenningsson A, Bergman J, Dring A, et al. Rapid depletion of B lymphocytes by ultra-low-dose rituximab delivered intrathecally. Neurol Neuroimmunol Neuroinflamm 2015;2:e79. doi: 10.1212/NXI.0000000000000079.

5. Hacohen Y, Absoud M, Deiva K, et al; United Kingdom Childhood Inflammatory Demyelination (UK-CID) and French Kidbiosep Study Groups. Myelin oligodendrocyte glycoprotein antibodies are associated with a non-MS course in children. Neurol Neuroimmunol Neuroinflamm 2015;2:e81. doi: 10.1212/NXI.0000000000000081.

6. Rostasy K, Mader S, Schanda K, et al. Anti-myelin oligodendrocyte glycoprotein antibodies in pediatric patients with optic neuritis. Arch Neurol 2012;69:752-756.

7. De Raedt S, De Vos A, Van Binst AM, et al. High natural killer cell number might identify stroke patients at risk of developing infections. Neurol Neuroimmunol Neuroinflamm 2015;2:e71. doi: 10.1212/NXI.0000000000000071.

8. Elkins J, Sheridan J, Amaravadi L, et al. CD56 $6^{\text {bright }}$ natural killer cells and response to daclizumab HYP in relapsingremitting MS. Neurol Neuroimmunol Neuroinflamm 2015;2:e65. doi: 10.1212/NXI.0000000000000065.

9. Bar-Or A, Wiendl H, Miller B, et al. Randomized study of teriflunomide effects on immune responses to neoantigen and recall antigens. Neurol Neuroimmunol Neuroinflamm 2015;2:e70. doi: 10.1212/NXI.0000000000000070.

10. Guptill JT, Yi JS, Sanders DB, et al. Characterization of B cells in muscle-specific kinase antibody myasthenia gravis. Neurol Neuroimmunol Neuroinflamm 2015;2:e77. doi: 10.1212/NXI.0000000000000077.

11. Yi JS, Guidon A, Sparks S, et al. Characterization of CD4 and CD8 $\mathrm{T}$ cell responses in MuSK myasthenia gravis. J Autoimmun 2014;52:130-138.

12. Moore CS, Ase A, Kinsara A, et al. P2Y12 expression and function in alternatively activated human microglia. Neurol Neuroimmunol Neuroinflamm 2015;2:e80. doi: 10.1212/ NXI.0000000000000080.

13. Marques IB, Flanagan S, Noble H, Giovannoni G, Marta M. Varicella-zoster virus encephalitis mimicking toxoplasmosis relapse. Neurol Neuroimmunol Neuroinflamm 2015;2:e74. doi: 10.1212/NXI.0000000000000074. 
14. Liba Z, Muthaffar O, Tang J, et al. Rasmussen encephalitis: response to early immunotherapy in a case of immune-mediated encephalitis. Neurol Neuroimmunol Neuroinflamm 2015;2:e69. doi: 10.1212/NXI. 0000000000000069.

15. Probst C, Komorowski L, de Graaf E, et al. Standardized test for anti-Tr/DNER in patients with paraneoplastic cerebellar degeneration. Neurol Neuroimmunol Neuroinflamm 2015;2:e68. doi:10.1212/NXI.0000000000000068.
16. Körtvelyessy P, Bauer J, Stoppel CM, et al. Complementassociated neuronal loss in a patient with CASPR2 antibody-associated encephalitis. Neurol Neuroimmunol Neuroinflamm 2015;2:e75. doi: 10.1212/NXI. 0000000000000075.

17. Simabukuro MM, Petit-Pedrol M, Castro LH, et al. GABA receptor and LGI1 antibody encephalitis in a patient with thymoma. Neurol Neuroimmunol Neuroinflamm 2015;2: e73. doi: 10.1212/NXI.0000000000000073. 


\section{Neurology \\ Neuroimmunology \& Neuroinflammation}

Identifying targets for diagnosis, prognosis, and treatment

Josep Dalmau

Neurol Neuroimmunol Neuroinflamm 2015;2;

DOI 10.1212/NXI.0000000000000087

This information is current as of April 2, 2015

Updated Information \&

Services

References

Permissions \& Licensing

Reprints including high resolution figures, can be found at:

http://nn.neurology.org/content/2/2/e87.full.html

This article cites 17 articles, 0 of which you can access for free at: http://nn.neurology.org/content/2/2/e87.full.html\#\#ref-list-1

Information about reproducing this article in parts (figures,tables) or in its entirety can be found online at:

http://nn.neurology.org/misc/about.xhtml\#permissions

Information about ordering reprints can be found online: http://nn.neurology.org/misc/addir.xhtml\#reprintsus

Neurol Neuroimmunol Neuroinflamm is an official journal of the American Academy of Neurology.

Published since April 2014, it is an open-access, online-only, continuous publication journal. Copyright $@$ 2015 American Academy of Neurology. All rights reserved. Online ISSN: 2332-7812.

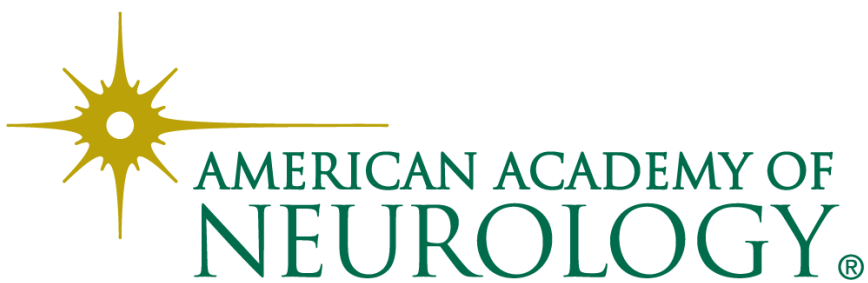

